\title{
Comparative analysis of innovation performance of European Union countries
}

\section{Komparativna analiza inovacijskog učinka zemalja Europske unije Enterprise}

\begin{abstract}
This paper aims to examine the innovation performance of 28 European Union countries. Hypothesis of the paper states there is a significant difference of innovation performance between the old and the new EU members. Furthermore, the role of SMEs regarding innovation capacity may not be the same across EU. Using K-means clustering results indicated Germany, Ireland, France, Luxemburg and Austria as the most innovative countries and Bulgaria, Estonia, Latvia, Hungary, Poland and Slovakia as the least innovative countries. Czech Republic, Croatia, Cyprus, Denmark, Finland, Greece, Italy, Lithuania, Malta, Netherlands, Portugal, Slovenia, Sweden, United Kingdom and Spain were found to have a medium level of innovation performance. Furthermore, United Kingdom surpassed the average innovation level of the cluster for the small sized enterprises. Croatia was below the average level of the cluster regardless of the size of the enterprise. Romania was the outlier with the least innovation. In order to facilitate more innovation these findings may be valuable in creating more country specific recommendations for entrepreneurial policy.
\end{abstract}

Keywords: cluster analysis, European Union, innovation, SME

JEL classification: 033, 044, 047

\section{Sažetak}

Cilj ovog rada je ispitati inovacijske učinke 28 zemalja Europske unije. Hipoteza rada navodi da postoji značajna razlika u inovacijskoj izvedbi između starih i novih članica EU. Nadalje, uloga MSP-a u pogledu inovacijskih kapaciteta možda nije na istoj razini u cijeloj EU. Korištenje rezultata klasteriranja K-sredinama označilo je Njemačku, Irsku, Francusku, Luksemburg i Austriju kao najinovativnije zemlje, a Bugarsku, Estoniju, Latviju, Mađarsku,Poljsku i Slovačku kao najmanje inovativne zemlje.Utvrđeno je da Češka, Hrvatska, Cipar,Danska,Finska, Grčka, Italija, Litva, Malta, Nizozemska, Portugal,Slovenija, Švedska, Velika Britanija i Španjolska imaju srednju razinu inovacijske izvedbe. Nadalje, Ujedinjeno Kraljevstvo premašilo je prosječnu razinu inovativnosti klastera za mala poduzeća. Hrvatska je bila ispod prosječne razine klastera bez obzira na veličinu poduzeća. Rumunjska je odstupala s najmanje inovacija. Kako bi se olakšalo više inovacija, ovi nalazi mogu biti korisni u stvaranju više preporuka za poduzetničku politiku specifičnih za pojedinu zemlju.

Ključne riječi: analiza klastera, Europska unija, inovacije, MSP

JEL klasifikacija: 033, 044, 047

\section{Ivan Novak}

Asst. prof.

Faculty of economics and Business, University of Zagreb E-mail: inovak1@net.efzg.hr

\section{Ivan Novak}

Doc.dr.sc.

Ekonomski fakultet Sveučilišta u Zagrebu E-mail: inovak1@net.efzg.hr 
Novak, I.

Comparative analysis of innovation performance of European Union countries

\section{Introduction}

Evermore important role of innovation is reflected in job formation, more sustainable technologies, increasing quality of life and maintaining EU's competitive edge. Innovation is a key pillar in technological and industrial policy necessary in conveying new ideas to market. Innovation has long been recognized as an important driver of the economic growth yet countries sometimes struggle in their efforts to boost it. Creating Innovation Union is one of the seven flagship initiatives of the Europe 2020 strategy for a smart, sustainable and inclusive economy. Innovation union is striving to remove innovation barriers, reinvent public and private cooperation and become the leading scientific performer. Final result of the Innovation Union would be the establishment of the single European market for innovation with the purpose of attracting even more entrepreneurs and business. In order to achieve this goal EU employs various measures in areas such as patent protection, standardization, public procurement and smart regulation. Emphasis is put on the private sector investments and increasing the EU venture capital investments (European parliament, 22.10.2020). Nevertheless, due to different country backgrounds not all members have managed to achieve the same level of innovation performance. European Union consists from 27 countries with United Kingdom arrangements being effective until the ending of the transition period in December 2020. EU15 encompassing Austria, Denmark, Belgium, Finland, France, Germany, Greece, Italy, Ireland, Luxembourg, Netherlands, Portugal, Spain, Sweden, and United Kingdom are considered to be the EU core countries. Later enlargement occurring in three stages with CEE and Baltic countries (Czech Republic, Slovak Republic, Poland, Slovenia, Hungary, Estonia, Latvia Lithuania) joining in 2004 as well as Malta and Cyprus, Bulgaria and Romania in 2007 and Croatia in 2013 has led to a higher degree of heterogeneity inside the European Union. According to the common notion that the level of a development and innovation performance is highly interconnected less developed countries should have a lower level of innovation performance. Identifying and understanding different clusters of innovation performance inside the EU may lead to efforts moderating those discrepancies as barriers to more sustainable development. This paper aims to examine and compare the level of innovation performance across the European Union bringing additional insight into innovation capacities of each country and the role of small and medium sized enterprises.

The remainder of the paper encompasses five sections. Second section provides literature overview describing previous research on the selected topic. Third section provides data description and applied methodology. Fourth section describes empirical results followed by the short discussion. Fifth and final section summarizes papers findings.

\section{Literature overview}

Most recent 19th European Innovation Scoreboard (EIS) 2020 assessment emphasizes steady increase of innovation performance in the European Union countries. This evaluation was based on the four types of activity (framework conditions, investments, innovation activities, impacts) considering for 10 innovation dimensions including total of 27 indicators (see Table 6 in Appendix). Most advancement is related to broadband penetration, international scientific cooperation and non R\&D investments. Inside EU convergence was present due to the catching up of less innovative countries. Denmark, Netherlands, Finland, and Sweden and Portugal were identified as innovation leaders. Luxemburg, Ireland, Belgium, France, Germany, Austria, Estonia were identified as strong innovators while Italy, Croatia, Slovenia, Czech Republic, Slovakia, Hungary, Poland, Latvia, Lithuania, Greece, Malta, Cyprus and Spain were identified to perform below the average innovation performance. Bulgaria and Romania were the least innovative (European Commission, 2020). Extension of the study called RIS 2019 used 18/27 of previously mentioned indicators confirming that most innovative regions are located in the most innovative countries (European Commission, 22.10.2020). Nevertheless, according to Edquist et al. (2018), Innovation Scoreboard is highly criticized for its results being misleading for the researchers, policy makers and the public. Using many separate indicators to calculate a single composite (Summary 
Innovation Index (SII)) lead to bias country ranking results.Authors emphasize importance of additional in depth analysis to acquire more representative measure of innovation performance.

Mejlgaard et al. (2019) compared 11 empirically anchored dimensions of Responsible Research and Innovation (RRI) across the European Union countries. According to empirical data hierarchical clustering identified 4 groups of similar countries. Additionally authors delivered a low-resolution map of the European RRI landscape. Bilas (2020) provided overview of the existing European Union innovation performance and smart specialization strategies. Results confirmed significant difference of innovation performance and different speeds of smart specialization strategy implementation. Nevertheless most countries focused on similar areas such as key enabling technologies, digital agenda, energy, health, agri-food etc. Kastrinos \& Weber (2020) highlighted that EU framework for $R \& l$ in the period 2021-2027 was being orientated toward sustainable development goals. Beltrán-Esteve \& Picazo-Tadeo (2017) emphasizes environmental performance and catching up from the new EU members joining in 2004.

Ivanová \& Čepel (2018) investigated connection of innovation performance and competitiveness in 4 European Union transition economies: Czech Republic, Hungary, Poland, and Slovakia. Analyzed countries had similar economic development but global competitiveness was highly dependent on innovation performance. Czech Republic was the leading innovator. Poland was found to have a balanced development while Hungary and Slovakia lagged behind. Klement et al. (2016) investigated Slovakia's innovation performance using data from Eurostat and the national Statistical Office. Paper examined the Slovakian position and revealed most important SMEs' barriers to innovation.

Crişan et al. (2018) focused their examination on the European Union least performing countries: Bulgaria and Romania. According to the SII data in the period from 2010 to 2016 EU innovation performance has increased but not all members participated equally. After 2012 Bulgaria has experienced rising innovation performance while Romania with the exception of the final year reduced its innovation performance. Additionally, comparative analysis of the selected countries has demonstrated interchanging leading and lagging position of the various innovation indicators.

Carvalho \& Yordanova (2018) explored the reasons behind the lack of innovation activities in more than half of European SME population. Consistent with previous research authors emphasize problem of funding and the lack of competition. Less consistent was the finding that increasing demand will not stimulate more innovative activities. De Marco et al. (2020) emphasized that even programs specifically oriented to European SME innovation may not necessarily manage to acquire target enterprises. Norek (2017) analyzed innovation projects supported by EU directed to SME in Slovakia and found no significant difference for participating and non-participating enterprises. Radicic et al. (2016) argued that SME support programs do stimulate innovation but the process of enterprise selection is not effective therefore needing revision. Ivanová \& Kordos (2017) investigated sources of SME funding in Slovakia. Results showed that only $17 \%$ of total financing was originated from the European Union sources. Recommendation was to increase the external sources of financing including EU funding programs and venture capital.

Consequently, to selected indicators and applied methodology results of the studies may vary. Innovation is a complex phenomenon including many variables therefore selection of the appropriate data is often not easy. Even the adequate measurement of innovation may not necessarily consider for impact. This creates an ongoing debate in the field of innovation research. Nevertheless, according to previous studies some common facts should be emphasized. Average innovation performance of EU has increased but each country development and the level of innovation is not the same.

\section{Data and methodology}

In 2007 European Union in cooperation with OECD has designed entrepreneurship indicator program (EIP) to ensure internationally comparable policy relevant indicators aiming to follow up entrepreneurship activities, determinants and impact. Set of indicators was developed to measure and monitor multidimensional entrepreneurship
Novak, I.

Comparative analysis of innovation performance of European Union countries 
Novak, I.

Comparative analysis of innovation performance of European Union countries phenomenon. There are 18 most important indicators dealing with enterprises, employment and wealth creation (see Table 7. in Appendix). This paper aims to examine the wealth creation dimension of entrepreneurship selecting innovation performance as the key indicator. Since the data is collected on voluntary basis many of the wealth creation indicators are not available (highgrowth enterprise data, gazelle enterprise data) or non-suitable for cluster analysis and following country comparison (exports, productivity, value added at factor cost).

Innovation performance data is acquired from the most recent community innovation survey (CIS) in 2014 encompassing enterprise data about new products, processes, marketing methods and organizational practice. Data is available considering for the size of the enterprise. Enterprises are divided in three groups: 10-49; 50-249 and more than 250 employees. Definition of the product innovative enterprise implies introduction of new or improved goods or services regarding their capabilities, user friendliness, components or sub-systems. Esthetic changes and simple resale of products acquired from other enterprises are not considered as innovation valid. Process innovative enterprises imply changes in production, distribution or supply activities. Organizational innovations imply changes of the workplace organization, organizational method in business practices or external relations. Marketing innovations imply new concepts and strategies significantly different from previous operations. Seasonal or regular marketing changes do not qualify for innovation. If the enterprise has conducted at least one of these activities in the last two years regardless of their origin of development it is classified as innovative. Innovations may be successfully implemented but not necessarily commercialized, on-going or even abandoned.

In order to examine the innovation performance of European Union countries this paper employs cluster analysis. Methodology is adopted and adjusted accordingly from Arora \& Varshney (2016). Using iterative techniques cluster analysis identifies objects with similar characteristics potentially reveling interesting patterns. K-means is one of the most popular partitioning algorithms for clustering. Clustering is performed by the Euclidian proximities. It takes ky as a user defined parameter and partition a set of $n$ objects from the selected number of clusters (ky). The mean value of the object is taken as the similarity parameter to create clusters. Center of the cluster is calculated by choosing the random selection of the ky object. By comparing proximities other cases are assigned to the cluster. For each data vector selected algorithms calculates proximity between the data vector and the cluster centroid using the following equation (1):

$$
D(P x, C j)=\left(\sum(P x, K y-C j, K y)\right)^{1 / 2}
$$

where $P_{x}$ is $x^{\text {th }}$ data point

$$
\text { and } C_{j} \text { is the centroid of } j^{\text {th }} \text { cluster. }
$$

The centroid is iteratively calculated after each addition of data point in cluster j. Calculation is performed using the following equation (2):

$$
C j=\frac{1}{N j \sum P x}
$$

where $\mathrm{N}_{\mathrm{j}}$ is the number of data point in cluster $\mathrm{j}$.

According to selected methodology next section of the paper presents results accompanied by the short discussion.

\section{Results and discussion}

Prior to cluster analysis, short examination of the most and the least innovative countries considering for the role of SMEs are given as follows. Data for each country is available in the Figure 1.

According to Eurostat data Romania was the country with the least portion of innovative enterprises (10-49 employees: 11.5\%; 50-249 employees: 15\%; 250+: 26.9\%) significantly lagging from the EU average. Highest proportion of the large sized (250+ employee) innovative enterprises was found in Germany (93.9\%), Austria (89.3\%) and Lithuania (87.7\%). Lowest proportion of the large sized innovative enterprises was found in Romania (26.9\%), Slovakia (54.7\%) and Hungary (55.1\%). Highest proportion of the innovative 


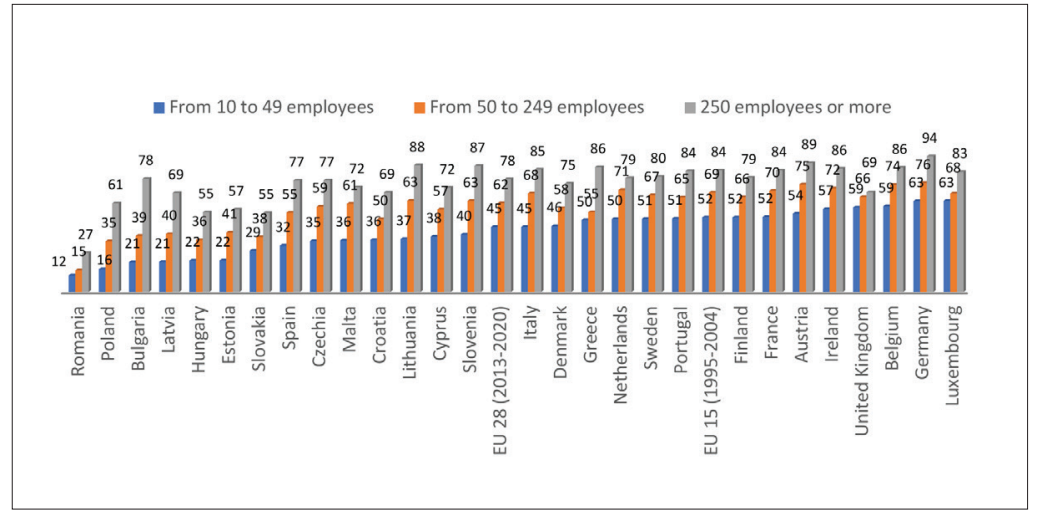

Source: Eurostat, [inn_cis9_type] sorted by innovation activities of enterprises with 10-49 employees.

medium sized enterprises (50-249 employees) was found in Germany (75.5\%), Austria (74.5\%) and Belgium (74.2\%). Lowest proportion of the medium sized innovative enterprises was found in Romania (15\%), Poland (35\%) and Hungary (35.9\%). Highest proportion of the innovative small sized enterprises (10-49 employees) was found in Luxemburg (63.1\%), Germany (62.9\%) and Belgium (59.4\%). Lowest proportion of the innovative small sized enterprises (10-49 employees) was found in Romania (11.5\%), Poland (15.7\%) and Bulgaria (20.6\%).

Since the k-means approach needs predefined number of clusters process was conducted recursively in order to reach the sensible framework. First clustering attempts confirmed Romania as the outlier consequently forming a separate cluster. Pop (2018) recognized Romanian efforts to catch up. Subsequently to substantial disbursement of non-reimbursable financing Romanian SMEs are now trying to boost up their innovation activities. Without inclusion of Romania European Union countries and United Kingdom were classified in
Table 1 Discriminatory power of innovativeness considering for the size of the enterprise

\begin{tabular}{|l|c|}
\hline 10 to 49 employees & F test \\
\hline 50 to 249 employees & 45.7 \\
\hline $250+$ employees & 85.8 \\
\hline
\end{tabular}

Source: author's own calculation.

3 clusters. Results of cluster analysis are given in Tables 1-4. Table 1 shows discriminatory power of innovativeness considering for the size of the enterprise.

Discriminatory power results indicate countries differentiate mostly according to innovation performance of small ( $\mathrm{F}=45.7)$ and medium sized enterprises ( $\mathrm{F}=85.8)$ emphasizing latter. Least discriminatory was the innovation performance of large enterprises $(F=21.0)$. Table 2 shows the final cluster centers.

According to the center cluster values it is evident that the first cluster of countries has the highest innovation performance including 6 countries:

Table 2 Final cluster centers

\begin{tabular}{|l|c|c|c|}
\hline 10 to 49 employees & High innovativeness & Low innovativeness & Medium innovativeness \\
\hline 50 to 249 employees & 58.1 & 21.5 & 43.6 \\
\hline $250+$ employees & 72.3 & 38.1 & 61.6 \\
\hline
\end{tabular}

Source: author's own calculation. 
Novak, I.

Comparative analysis of innovation performance of European Union countries

Table 3 Distance between final cluster centers

\begin{tabular}{|c|c|c|c|}
\hline Cluster & 1 & 2 & 3 \\
\hline 1 & & 55.765 & 19.830 \\
\hline 2 & 55.765 & & 36.100 \\
\hline 3 & 19.830 & 36.100 & \\
\hline
\end{tabular}

Source: author's own calculation.

Belgium, Germany, Ireland, France, Luxembourg and Austria. Large sized enterprises have the highest proportion of innovative enterprises $(86.97 \%)$ followed by medium $(72.35 \%)$ and small sized (58.12\%) enterprises. Second cluster includes countries with the lowest innovation performance including 6 countries: Bulgaria, Estonia, Latvia, Hungary, Poland and Slovakia (large sized enterprises: $62.4 \%$, medium sized enterprises: $38.1 \%$, small sized enterprises: $21.5 \%)$. Third cluster is the group with medium level of innovative enterprises including 15 countries: Czech Republic, Croatia, Cyprus, Denmark, Finland, Greece, Italy, Lithuania, Malta, Netherlands, Portugal, Slovenia, Sweden, United Kingdom and Spain (large sized enterprises: $78.6 \%$, medium sized enterprises: $61.6 \%$, small sized enterprises: $43.6 \%$ ). Countries with least innovation activities lagged the most in the segment of SMEs specifically enterprises with less than 50 employees. This may be explained by the lack of funding for the smallest enterprises in the newly joined members. Box-plot diagram was constructed to examine the similarity of countries in the same cluster (see Figure 2 in Appendix). First cluster was the most homogenous. Third cluster was the least homogenous with United Kingdom and Croatia being the outliers. United Kingdom surpassed the average innovation level of the cluster for the small sized enterprises and Croatia was below the average level of the cluster regardless of the size of the enterprise. (see Figure 1). Table 3 shows distance between the final cluster centers. Matrix is symmetrical.

Table 4 Cluster information for each country

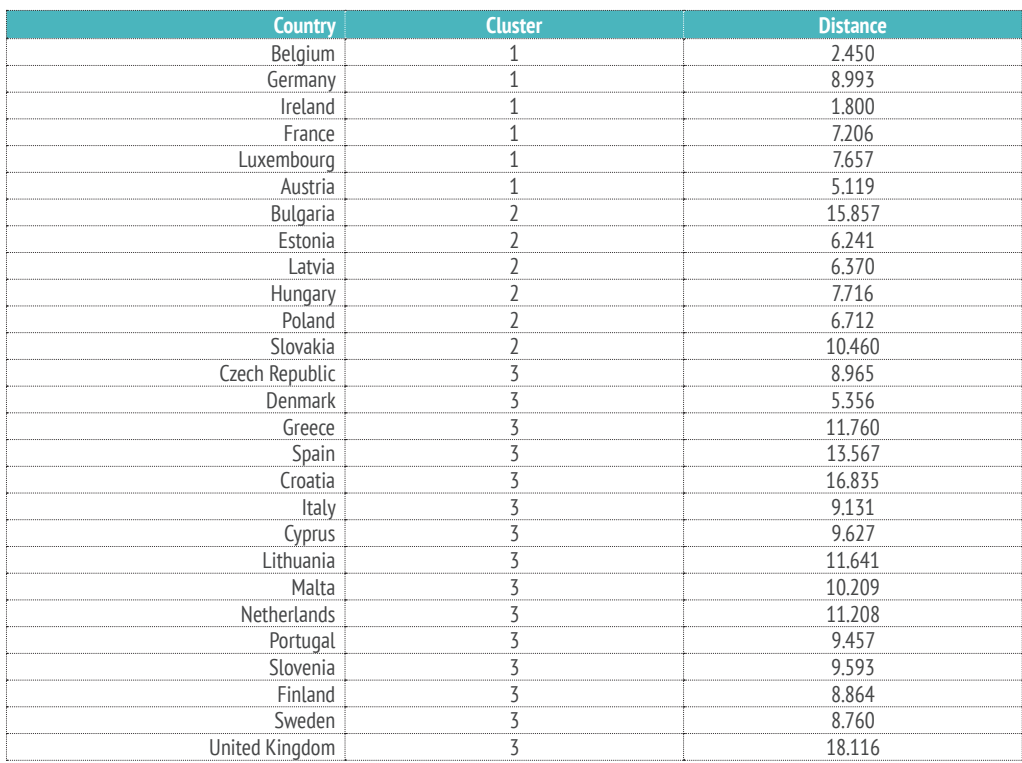

Source: author's own calculation. 
Center distance reflects the level of similarities for the group of countries in each cluster. Greatest distance was detected between the most developed core EU countries with the highest innovation performance and the less developed new EU countries $(D=55.765)$. The greatest similarity was between countries in the first and the third group $(D=19.831)$. Table 5 shows the cluster information value for each country reflecting its position regarding the average value of the group.

Germany was found to surpass the average level of innovation performance of the first and most innovative cluster of EU countries regardless the size of the enterprise $(62.9 \%, 75.5 \%, 93.9 \%)$ $(D=8.993)$. Bulgaria was found to surpass the average innovation performance of the second cluster with $78.3 \%$ of innovative large sized enterprises $(D=15,857)$. Besides already identified outliers such as Croatia and United Kingdom, Spain was found to lag behind the average innovation performance of the third cluster regardless of the size of the enterprise $(32.0 \%, 54.9 \%, 77.1 \%)(D=13,567)$.
In order to achieve more comprehensive analysis cluster results are further supplemented with the information about the specific type of innovation in each European Union country (see Table 5).

Ireland (35.7\%), Finland (34.5\%) and Germany (34.4\%) were found to excel in product innovation while Romania (3.6\%), Latvia (8.5\%) and Poland (9.5\%) lagged the most. Belgium (38.8\%), Ireland (37.8\%) and Portugal (35.4\%) were found to excel in process innovation while Romania (4.3\%), Bulgaria (9.2\%) and Hungary (9.6\%) lagged the most. Ireland (39.6\%), Germany (35.9\%) and Luxembourg (34.1\%) were found to excel in marketing innovation while Romania (6.6\%), Poland (7.8\%) and Hungary $(11.3 \%)$ lagged the most. Luxembourg (47\%), Ireland (44.4\%) and UK (40.1\%) were found to excel in organization innovation while Romania (6.7\%), Poland (9.0\%), Hungary (9.6\%) lagged the most. Netherlands was found to rank the 4th by the proportion of enterprises with product innovation even though being in the cluster with medium level of innovation performance. Similarly, Portugal

Table 5 Type of innovation activity by each country

\begin{tabular}{|c|c|c|c|c|c|c|c|}
\hline Country & Product & Country & Process & Country & Marketing & Country & Organization \\
\hline Ireland & 35.7 & Belgium & 38.8 & Ireland & 39.6 & Luxembourg & 47.0 \\
\hline Finland & 34.5 & Ireland & 37.8 & Germany & 35.9 & Ireland & 44.4 \\
\hline Germany & 34.4 & Portugal & 35.4 & Luxembourg & 34.1 & UK & 40.1 \\
\hline Netherlands & 32.5 & Austria & 32.8 & Greece & 32.5 & Germany & 37.8 \\
\hline Belgium & 31.9 & Finland & 32.0 & Austria & 29.8 & Austria & 37.3 \\
\hline Sweden & 31.4 & Lithuania & 31.4 & Denmark & 29.0 & Belgium & 35.9 \\
\hline Austria & 30.8 & Greece & 29.6 & Portugal & 29.0 & France & 35.0 \\
\hline Luxembourg & 28.8 & Netherlands & 28.1 & Belgium & 28.4 & Denmark & 30.1 \\
\hline Portugal & 28.4 & Cyprus & 27.6 & Sweden & 28.1 & Finland & 29.7 \\
\hline France & 27.7 & France & 27.1 & Finland & 25.9 & Malta & 26.4 \\
\hline UK & 26.8 & Sweden & 25.8 & Cyprus & 25.5 & Portugal & 25.9 \\
\hline Slovenia & 25.2 & Luxembourg & 25.7 & France & 25.3 & Greece & 25.5 \\
\hline Czech Rep. & 25.1 & Italy & 24.5 & Slovenia & 25.1 & Netherlands & 25.2 \\
\hline Italy & 24.7 & Germany & 24.1 & Croatia & 23.6 & Cyprus & 25.0 \\
\hline Denmark & 24.4 & Denmark & 23.7 & Italy & 23.5 & Italy & 24.5 \\
\hline Greece & 23.4 & Slovenia & 22.6 & Czech Rep. & 20.5 & Slovenia & 24.4 \\
\hline Cyprus & 22.9 & Czech Rep.. & 22.4 & Malta & 20.0 & Croatia & 23.2 \\
\hline Lithuania & 20.9 & Croatia & 21.6 & Netherlands & 20.0 & Sweden & 22.7 \\
\hline Malta & 19.6 & Malta & 20.8 & Lithuania & 18.7 & Spain & 21.8 \\
\hline Croatia & 18.7 & UK & 17.9 & UK & 18.5 & Czech Rep. & 17.1 \\
\hline Slovakia & 12.6 & Spain & 14.8 & Slovakia & 16.8 & Lithuania & 16.7 \\
\hline Hungary & 12.0 & Estonia & 13.0 & Spain & 15.8 & Latvia & 14.9 \\
\hline Spain & 11.2 & Slovakia & 12.9 & Latvia & 13.6 & Slovakia & 14.7 \\
\hline Estonia & 11.0 & Poland & 10.9 & Estonia & 12.1 & Bulgaria & 10.8 \\
\hline Bulgaria & 10.9 & Latvia & 9.7 & Bulgaria & 11.7 & Estonia & 10.4 \\
\hline Poland & 9.5 & Hungary & 9.6 & Hungary & 11.3 & Hungary & 9.6 \\
\hline Latvia & 8.5 & Bulgaria & 9.2 & Poland & 7.8 & Poland & 9.0 \\
\hline Romania & 3.6 & Romania & 4.3 & Romania & 6.6 & Romania & 6.7 \\
\hline
\end{tabular}

Source: Eurostat, [inn_cis9_type]. 
Novak, I.

Comparative analysis of innovation performance of European Union countries was found to rank the 3rd by the proportion of the process innovation enterprises even though being in the same cluster.

Results of the cluster analysis indicate that not all European Union countries achieve the same level of innovation performance. Not even the core EU countries show the similar level of innovation performance. Denmark, Italy, Finland, Greece, Netherlands, Spain, Sweden and United Kingdom are the core EU countries but do not exemplify the highest level of innovation performance. Also, some countries deviated relatively more from the average level of innovation performance in the appointed cluster. Since these variations may not be attributed solely to country development specific country circumstances should be further considered.

\section{Conclusion}

This paper brings several conclusions. While considering for outliers according to the proportion of innovative enterprises European Union countries may be divided in 3 clusters: low, medium and high level of innovation performance. Furthermore, neither the EU membership nor the country's level of development may fully explain these variations. Results may help to create country specific policies aiming to further boost innovation performance. Policies should aim to increase efficiency in resource allocation. Market mechanisms offer great potential in reaching desired goals and failure is mostly the consequences of inability to insure the free market requirements. Some of the EU innovation measures already tackle these barriers. Nevertheless, for some countries to catch up national policies should deal with specific inconsistencies potentially more present in their countries. Likewise, policies that will increase the EU convergence may be the cornerstones of EU's long-term competitiveness. Limitations of the research stems from the lack of more recent community innovation survey data. Furthermore, cluster analysis is based on the number of innovative enterprises without considering for impact of those innovations. Future research may focus on the specific country profiles identifying existing systemic barriers to higher innovation performance.

\section{References}

Arora, P., Varshney, S. (2016) Analysis of k-means and k-medoids algorithm for big data. Procedia Computer Science, 78: 507-512.

Beltrán-Esteve, M., Picazo-Tadeo, A. J. (2017) Assessing environmental performance in the European Union: Eco-innovation versus catching-up. Energy Policy, 104: 240-252.

Bilas, V. (2020) Smart specialisation concept as a tool for improving innovation performance of the European Union member states. Ekonomski Vjesnik, 33(1): 217-226.

Carvalho, N., Yordanova, Z. (2018) Why say no to innovation? Evidence from industrial SMEs in European Union. Journal of technology management \& innovation, 13(2): 43-56.

Crişan, D.A.,Preda,A.M.,Stănică,J.L.,Samuel,A.N.A.(2018) Innovation Performance Analysis for European Union Countries Focused on Modest Innovators: Romania and Bulgaria. Journal of Information Systems \& Operations Management, 30-44.

De Marco, C. E., Martelli, I., Di Minin, A. (2020) European SMEs' engagement in open innovation When the important thing is to win and not just to participate, what should innovation policy do? Technological Forecasting and Social Change, 152:119843.

Edquist, C., Zabala-Iturriagagoitia, J. M., Barbero, J., Zofío, J. L. (2018) On the meaning of innovation performance: Is the synthetic indicator of the Innovation Union Scoreboard flawed? Research Evaluation, 27(3): 196-211. 
European Commission (2020) European Innovation Scoreboard 2020. Luxembourg: Publications Office of the European Union.

European Commission, Regional Innovation Scoreboard. Available at: https://ec.europa.eu/growth/ industry/policy/innovation/regional_en [22.10.2020].

European parliament, Innovation policy. Available at: https://www.europarl.europa.eu/factsheets/en/ sheet/67/innovation-policy [22.10.2020].

Eurostat database.Available at: https://ec.europa.eu/eurostat/data/database [22.10.2020].

Ivanová, E., Čepel, M. (2018) The impact of innovation performance on the competitiveness of the Visegrad 4 countries. Journal of Competitiveness, 10(1): 54.

Ivanová, E., Kordos, M. (2017) Innovation policy of SMEs in Slovakia in the context of European Union innovation policy. Маркетинг і менеджмент інновацій, (3): 213-225.

Kastrinos, N., Weber, K. M. (2020) Sustainable development goals in the research and innovation policy of the European Union. Technological Forecasting and Social Change, 157: 120056.

Klement, L., Lesáková, L'., Klementová,V., Elexa, L'. (2016,September) Innovation performance of the Slovak Republic. In Forum Scientiae Oeconomia, 4(3): 115-126.

Mejlgaard, N., Bloch, C., Madsen, E. B. (2019) Responsible research and innovation in Europe: A crosscountry comparative analysis. Science and Public Policy, 46(2): 198-209.

Norek, T. (2017) Analysis of the efficiency of innovation projects supported by the EU funds-a case study of Polish SME companies. V Entrepreneurs. entrepreneurship: challenges and opportunities in the 21st century, 74-88.

Pop,A. M. (2018) The evolution of the Romanian SMES after Romania's integration in the European Union structures. Modelling the New Europe. An On-line Journal, 27: 148-159.

Radicic, D., Pugh, G., Hollanders, H., Wintjes, R., Fairburn, J. (2016) The impact of innovation support programmes on SME innovation in traditional manufacturing industries: an evaluation for seven EU regions. Environment and Planning C: Government and Policy, 34(8): 1425-1452.

Sandu, S.,Anghel, I. (2016) Social innovation and innovation performance in the European Union. Annales Universitatis Apulensis: Series Oeconomica, 18(1): 57. 


\section{Appendix}

Novak, I.

Comparative analysis of innovation performance of European Union countries
Figure 2 Cluster homogeneity and country outliers

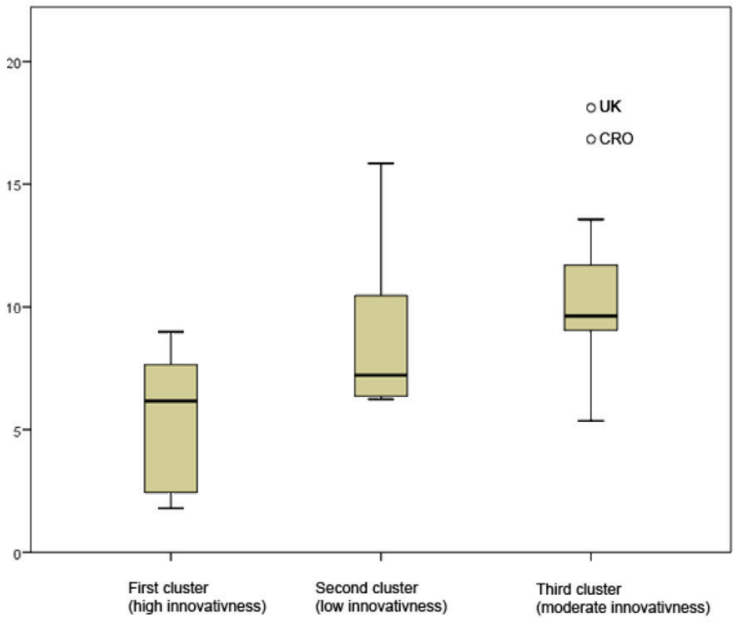

Source: author's own calculation.

Table 6 European Innovation Scoreboard 2020 innovation dimensions including 27 indicators

\begin{tabular}{|c|c|c|}
\hline SUMMARY INNOVATION INDEX & R\&D expenditure in the business sector & Employment impacts \\
\hline Human resources & Non- $R \& D$ innovation expenditures & $\begin{array}{r}\text { Employment in knowledge-intensive } \\
\text { activities }\end{array}$ \\
\hline New doctorate graduates & Enterprises providing ICT training & Employment fast-growing enterprises \\
\hline Population with tertiary education & Innovators & Sales impacts \\
\hline Lifelong learning & SMEs product/process innovations & Medium and high-tech product exports \\
\hline Attractive research systems & $\begin{array}{r}\text { SMEs marketing/organizational } \\
\text { innovations }\end{array}$ & Knowledge-intensive services exports \\
\hline International scientific co-publications & SMEs innovating in-house & Sales of new-to-market/firm innovations \\
\hline Most cited publications & Linkages & \\
\hline Foreign doctorate students & $\begin{array}{r}\text { Innovative SMEs collaborating with } \\
\text { others }\end{array}$ & \\
\hline Innovation-friendly environment & Public-private co-publications & \\
\hline Broadband penetration & Private co-funding of public R\&D exp. & \\
\hline Opportunity-driven entrepreneurship & Intellectual assets & \\
\hline Finance and support & PCT patent applications & \\
\hline R\&D expenditure in the public sector & Trademark applications & \\
\hline Venture capital expenditures & Design applications & \\
\hline Firm investments & & \\
\hline
\end{tabular}

Source: European Commission (22.10.2020). 
Table 7 Indicators of the Eurostat-OECD entrepreneurship indicator programme (EIP)

\begin{tabular}{|l|}
\hline Enterprises \\
\hline 1.Employer enterprise birth rates \\
\hline 2. Employer enterprise death rates \\
3. Employer enterprise churn \\
4. Employer enterprise net growth \\
5. Survival rates of 3 year and 5 -year-old enterprises \\
6. Share of 3 year and 5 -year-old enterprises \\
\hline Employment \\
\hline 7. High growth enterprise rates by employment \\
8. Gazelle rates by employment \\
9. Business ownership start Up rates \\
10.Business ownership rates \\
\hline 11. Employment share of 3 year and 5 -year-old enterprises \\
12. Average size of 3 year and 5 -year-old enterprises \\
\hline Wealth \\
13. High growth enterprise rates by turnover \\
\hline 14. Gazelle rates by turnover \\
15. Value added by size class \\
\hline 16. Productivity contribution by size class \\
17. Innovation performance by size class \\
18. Exports by size class \\
\hline
\end{tabular}

Source: Eurostat (2020). 
